\title{
The smash of Parthenium hysterophorus L. in the grasslands of Oman
}

\author{
Mahaad Issa Shammas \\ Department of Civil and Environmental Engineering, Dhofar University, Salalah 211, Sultanate of Oman \\ *Email: mahad@du.edu.om
}

\section{ARTICLE HISTORY}

Received: 23 January 2021

Accepted: 14 April 2021

Published: 30 April 2021

\section{KEYWORDS}

Parthenium hysterophorus

Weed

Biodiversity

Allelopathy

\section{ABSTRACT}

This study examines the invasiveness of Parthenium hysterophorus L. considered as harmful, unpleasant noxious invasive weed in Sultanate of Oman. Since the subject of investigation has allelopathic effects, the author's objective is to identify its abundance, its impact to environment, human and animal health. Allelopathy of this invasive weed has started to be known and considered by the farmers and harvesters. The harmful and socio-economic effects of the weed to humans, animals and to landscape are not fully known nor understood by the local farmers and pastoralists in the southern part of Oman where this weed is most invasive. Data were collected through field observation, informal interviews, focus group discussions and survey questionnaire. They were treated and analysed using descriptive statistics. Findings prompted the participants to propose possible and practical control solutions for the spread of $P$. hysterophorus if not totally eradicated, considering the availability of resources, level of awareness and the socio-economic status of the affected regions. The results of the investigation are hoped to improve the over-all management that are being conducted by the concerned agencies and volunteers towards the rapid spread of the weed. The findings revealed that $P$. hysterophorus has serious impacts on vegetation, pastures and agriculture, as it was observed in reduced level growth of both plants and trees. The possible control measures gathered from the participants indicate that they are willing to cooperate and learn more about the impact of the weed.

\section{Introduction}

Parthenium hysterophorus L. is invasive in the Sultanate of Oman characterized by allelopathic effects. This involves direct/indirect harmful with beneficial effects to one plant on another by producing chemical compounds that escape into the environment (1). Allelopathy of this invasive weed and its deleterious effects on the native vegetation has started to alarm the farmers and harvesters. The harmful and socio-economic effects of the weed to humans, animals to landscapes are not fully known nor understood by the local farmers and pastoralists of the southern part of Oman where this weed is most abundant. $P$. hysterophorus has spread rapidly in the last two decades during monsoon along the areas of the mountains of Dhofar (southern Oman) $(2,16)$. It started to become aggressive colonizer of wasteland, road sides, water courses, cultivated fields and overgrazed rangeland (3). Their pollen has been reported to cause various allergies in forms of asthma, hay fever and contact dermatitis among residents. The weed completes its life-cycle in 4-6 weeks, is deeprooted and under favourable conditions and forms dense growth in several locations in southern Oman (4).

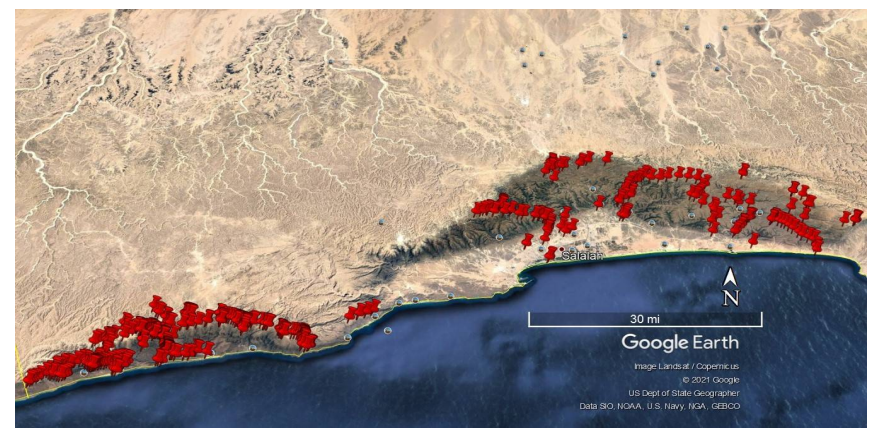

Fig. 1. Locations of Parthenium hysterophorus along Dhofar mountains, Oman.

(c) Shammas (2021). This is an open-access article distributed under the terms of the Creative Commons Attribution License, which permits unrestricted use, distribution and reproduction in any medium, provided the original author and source are credited (https://creativecommons.org/licenses/by/4.0/).

To cite this article: Shammas M I. The smash of Parthenium hysterophorus L. in the grasslands of Oman. Plant Science Today. 2021;8(2):392-402. https://doi.org/10.14719/pst.2021.8.2.1103 
Fig. 1 shows the abundance of the weed at Dhofar mountains indicating that it grew vigorously as shown by the 407 red bullet-coordinates dated December, 2020. It became the major weed not only Dhofar governorate but continued to extend its presence within and outside the southern part of the country.

Monitoring and control measures had been extended to avoid severe infestations and allelopathy (13). Most of the infestations are noticed along roadsides, residential areas, wasteland and crop farms as noticed by the farmers. The situation is subject to a quick spread through wind pressure of moving transports. It was observed too, that the plant constitutes more than $95 \%$ per square meter compared to other native species, thus affecting the abundance and palatable native plants for livestock, as well as reducing nutrient levels in the soil (5).

Following the stages of the weed, it was found that germination is during the monsoon period, which begins at the end of June and ends before the start of November each year. It produces its flowers
In 2020, volunteers agreed to hand-pull the weeds even without much knowledge of the harmful effects that it may cause to them. Concerned authorities in the Sultanate are making unremitting efforts to deal with this weed. MD 189 / 2020 was issued to form a joint working group headed by his Excellency, the Dhofar Municipality Chair including the representatives coming from: Dhofar Municipality; NFRCEC of DRC; General Directorate of Agriculture-Dhofar; MAFWR; General Directorate for the Environment-Dhofar; General Directorate for NC; MHESRI; SQU; and DU.

The team was assigned to undertake the tasks of setting a timetable to conduct necessary research study about the plant, specify its damage to the environment and humans, take necessary measures and procedures to eradicate it, coordinate with private sector institutions to support the efforts of the working team and take initiatives to provide community awareness on the danger and harmful effects of $P$. hysterophorus. The initiatives were planned due to the rapid invasion of the dangerous weed as shown in Fig. 2 where the residents and

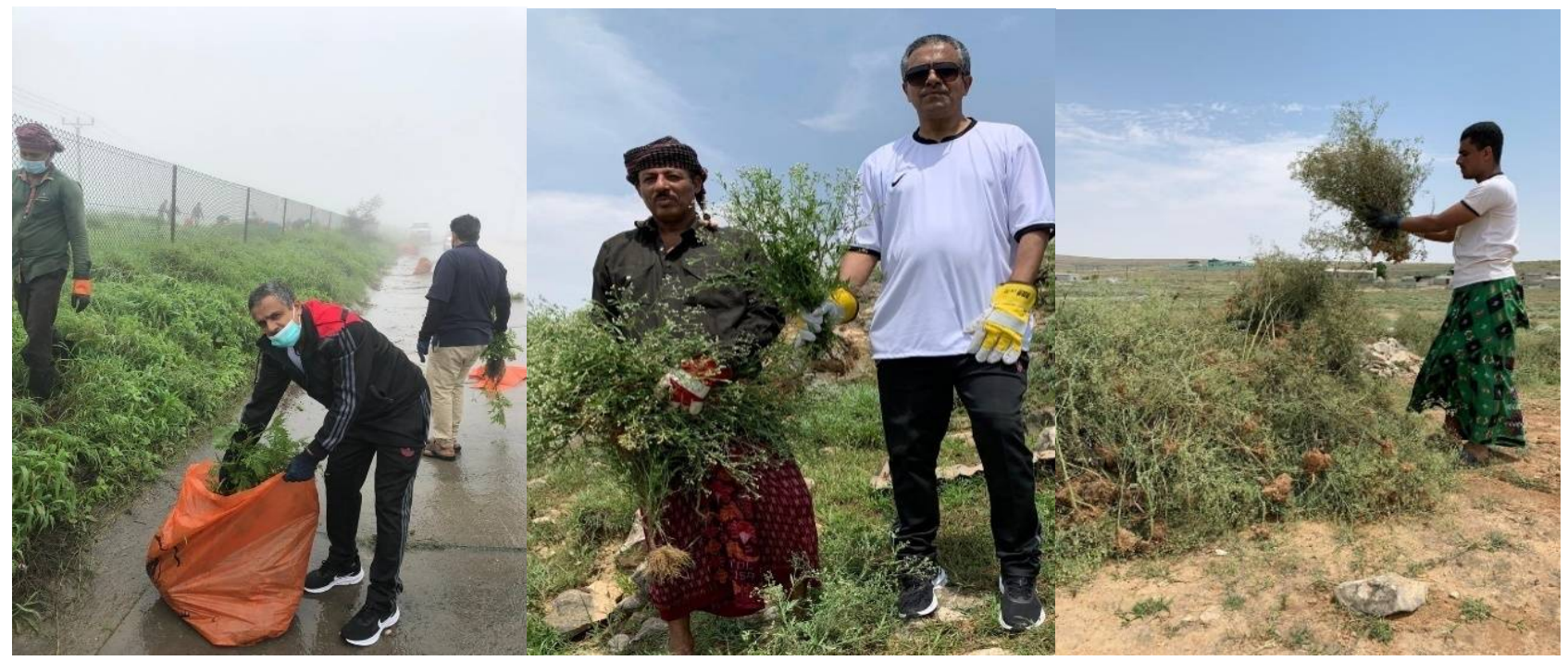

Fig. 2. Abundance of noxious Parthenium hysterophorus L. in Dhofar mountains, Oman.

and seeds throughout its short span of life until dies as the hot season arrives in Dhofar during March and April. It grows faster when the rain falls and as the climate saturated with humidity prevails in the region. Other factors that help the rapid spread include machinery being used by the residents and farmers in grazing their livestock (6).

Attempts have been made to control the spread of $P$. hysterophorus by the Anti-Parthernium campaigns composed of interested residents and started mid-July till August 2020. The entire team comprising of volunteers carried out daily manual weeding (before its flowering stage), burning and planting other plants to replace the weeds. Still they never apply chemical pesticides or any agents to biologically control them (7). The Environment Authority appreciated the efforts of the local community in the for rendering full cooperation and participation in the voluntary campaigns to eradicate the weed. volunteers including the author himself started to alarm.

\section{Materials and Methods}

\section{Research Design}

This research investigation utilized descriptive normative method of research in both qualitative and quantitative processes. A mixed method (8) using field research, informal interviews, personal observations substantiated by questionnaire were denoted August 2020. The initiatives evaluated the presence and abundance of $P$. hysterophorus in the grasslands of Dhofar. Focus group discussions (FGD) (9) was conducted to triangulate the results of the obtained data and informal interviews from the participants of the study. The method assessed the participant's perception on the weed, its hazardous impact to human health, animals, environment and 
biodiversity (10). The extent of responsiveness manifested to control the damage of the weed was also analyzed. The instruments also tested the significant differences among the assessment of the participants of the study.

\section{Participants of the Study}

The subjects of the study were the 255 participants composed of farmers, pastoralists, residents, businessmen, agriculturists, land owners, herdsmen, vehicle drivers, animal raisers, students and employees from both public and private sectors.

Purposive sampling was utilized to definitely determine the respondent's ability to answer the items listed in the survey questionnaire. This type of sampling, also called deliberate sampling, was preferred by the researcher because the samples were selected based on his decision and judgment on who best qualifies to accomplish the objectives of the study (11).

\section{Data Gathering Instruments}

The researcher made use of a self-made survey questionnaire supplemented by responses and feedbacks from the triangulation process. Observation was the foremost tool that was utilized since it determined who could really help the researcher to come up with the possibilities of engaging with this study. Direct observation was considered the prevailing method of inquiry to gather information concerning the aspects of $P$. hysterophorus presence in the region. In the triangulation too, the prepared informal interview substantiated with FGD helped the researcher to elicit the needed sufficient data.

\section{Construction of the Questionnaire}

The researcher had to undergo extensive readings of professional books, journals, unpublished theses, dissertations concerning issues on $P$. hysterophorus to gather sufficient items needed for the questionnaire. The thorough review and analysis of other instruments indulged the author to collect solid bases for the survey. The first part consists of demographic information of the participants. The second part dealt with assessment of the damaging impact of the weed (12) to human health, agriculture, animals, biodiversity and environment. Part three contains the responses of the participants in controlling the damage done by the weed. Whereas, part four assessed the problems encountered in controlling the spread of $P$. hysterophorus. The divergent control measures to prevent its spread for the conservation of biodiversity (13) were summarized, too. Data for all interviews were consolidated, reviewed and analyzed. In the survey questionnaire, the degree of the impact of the weed were identified and measured.

\section{Validation of the questionnaire}

To validate the instrument, the questionnaire was translated to Arabic and pilot tested through a dry run method among some academicians, students, residents and farmers. Likewise, the questionnaire was shown to research experts from the several agencies for clarity of directions, enrichment of content and editing procedures. After the dry run, valuators were interviewed regarding the clarity of the items. Unnecessary questions and items that were vague to the respondents were deleted, removed and simplified until further improved.

\section{Administration of the Survey}

The surveys were administered both personally and electronically to the respondents informing them the purpose of the study and how it would be treated with confidentiality.

\section{Scoring of Responses}

The survey assessed the participants' perception of $P$. hysterophorus on one's health and its hazardous impact to animals, environment, agriculture and biodiversity using the following five-point likert scale:

\begin{tabular}{ccl}
\hline Option & Scale Range & Verbal Interpretation \\
\hline 5 & $93-98$ & Strongly Agree \\
\hline 4 & $86-92$ & Agree \\
\hline 3 & $80-85$ & Neutral \\
\hline 2 & $70-79$ & Disagree \\
\hline 1 & $69-$ below & Strongly Disagree \\
\hline
\end{tabular}

Whereas, the extent of responsiveness manifested in controlling the damage done by $P$. hysterophorus were measured using the following five-point likert scale:

\begin{tabular}{ccl}
\hline Option & Scale Range & Verbal Interpretation \\
\hline 5 & $93-98$ & Very Great Extent \\
\hline 4 & $86-92$ & Great Extent \\
\hline 3 & $80-85$ & Moderately Extent \\
\hline 2 & $70-79$ & Least Extent \\
\hline 1 & 69 and below & Very Least Extent \\
\hline
\end{tabular}

For the problems encountered by the affected residents in controlling the spread of the weed, the following was used:

\begin{tabular}{ccl}
\hline Option & Scale Range & Verbal Interpretation \\
\hline 5 & $93-98$ & Always \\
\hline 4 & $86-92$ & Frequently \\
\hline 3 & $80-85$ & Sometimes \\
\hline 2 & $70-79$ & Seldom \\
\hline 1 & 69 and below & Never \\
\hline
\end{tabular}

\section{Data Analysis}

All data were tallied, encoded and analysed using different statistical tools. Shapiro Wilk determined the normality of the gathered data followed by parametric tests that include mean, standard deviation, till arrived the calculated shape of distribution. These were calculated for the continuous variables and frequencies that identified the categorical variables. Independent Sample T-test and Analysis of Variance (ANOVA) tested the comparison among variables under studied. For the 
pairwise multiple comparison, Bonferroni Test determined which among the variables occurred significant. Participants assessment were measured using a five-point Likert scale. To further compute and intepret the result, all data were treated using SPSS version 26 (14).

\section{Results}

Among the respondents, $88.80 \%$ were unaware of the inclusion of the plant in the Book of Recorded Plants in Oman published by the Diwan of Royal Court (15, 16). But there was positive awareness of the invasion of the plant in the country as evidenced by $91.20 \%$ positive responses. Still, there were $22.30 \%$ who declared that they were still not aware of the presence of the plant in their localities. As to awareness on its danger to one's health, to plants, animals and environment, $79.10 \%$ were knowledgeable and $20.90 \%$ were not.

\section{Hazardous impact of $P$. hysterophorus on human health}

All participants agreed that the weed developed hazardous health impact on them as evidenced by Agree verbal interpretation evidenced by 3.81 obtained composite mean. The following were verbally interpreted as Agree starting from highest to lowest rank: appearance of skin rashes, especially on face and hands (WM-4.20), causes various allergies, hay fever and bronchitis (WM-4.14), swelling and itching of the membranes of the mouth and nose (WM-3.91), running nose and frequent sneezing (WM3.73), fatigue and asthma (WM-3.71), constant coughing especially at night (WM-3.54) and causes nausea and dizziness (WM-3.53) (16).

Table 1 displays the reponses of participants on the impact of the weed to one's health. aided by a five-point likert scale: $4.50-5.00=$ Strongly Agree; $3.50-4.49$ = Agree $; 2.50-3.49=$ Neutral; $1.50-2.49=$ Disagree; $1.00-1.49$ = Strongly Disagree.

\section{Hazardous impact of $P$. hysterophorus on agriculture}

Table 2 shows the obtained responses from the participants as assessed and rated with the following responses: 4.50 - $5.00=$ Strongly Agree; $3.50-4.49=$ Agree; $2.50-3.49=$ Neutral; $1.50-2.49$ = Disagree; $1.00-1.49=$ Strongly Disagree and summarized accordingly: decreases the growth of plants and trees (WM-4.59), affects the germination of the seeds (WM4,54 ), produces more pollen and when carried away affects the fruits among crops (17) (WM-4.50) all of these were assessed by the participants with Strongly Agree verbal interpretation. Meanwhile the following were marked Agree: losses on harvest and quality deterioration of the harvested products (WM-4.38), contains chemicals harmful to crops (WM-4.21), infests vegetables and fruits crops (WM-4.00), inhibits the germination and growth of cereal crop, sorghum (18) (WM-3.96) and hinders the growth of radish (3.68).

\section{Hazardous impact of $P$. hysterophorus on animals}

The following indicators obtained Agree response from the participants as shown in Table 3: poses serious health hazards to livestock (WM-4.02), once eaten, toxic and causes dermatitis to horses and cattle (WM-3.93), inhibits mouth ulcers combined with excessive salivation (WM-3.91), causes acute illness in cows and dogs when fed on grass mixed with the weed (WM-3.91), kills cattle if eaten in large amount (19) (WM-3.81), weakens cows' immune system ability (WM-3.72), its extract, too, reduces rat blood count (WM-3.52). There was Neutral response from the participants, reflected in their unawareness on the given indicators: causes anorexia, pruritus, alopecia, diarrhea and eye irritation among dogs (20) (WM-3.47). A five-point likert scaling measured the participants' assessment:4.50 - 5.00 = Strongly Agree; 3.50 - 4.49 = Agree; $2.50-3.49=$ Neutral; $1.50-2.49=$ Disagree; 1.00 - 1.49 = Strongly Disagree .

Table 1. Hazardous impact of $P$. hysterophorus on human health

\begin{tabular}{|c|c|c|c|c|c|}
\hline & Indicators & $\mathbf{M}$ & SD & VI & $\mathbf{R}$ \\
\hline 1 & various allergies, hay feverand bronchitis & 4.14 & 0.903 & Agree & 2 \\
\hline 2 & nausea and dizziness & 3.53 & 0.936 & Agree & 8 \\
\hline 3 & skin rashes, especially on face and hands & 4.20 & 0.844 & Agree & 1 \\
\hline 4 & watery eyes & 3.68 & 0.867 & Agree & 6 \\
\hline 5 & swelling and itching of the membranes of the mouth and nose & 3.91 & 0.865 & Agree & 3 \\
\hline 6 & constant coughing especially at night & 3.54 & 0.900 & Agree & 7 \\
\hline 7 & running nose and frequent sneezing & 3.73 & 0.928 & Agree & 4 \\
\hline \multirow[t]{2}{*}{8} & fatigue and asthma & 3.71 & 0.870 & Agree & 5 \\
\hline & Composite Mean & 3.81 & 0.717 & Agree & \\
\hline
\end{tabular}

Table 2. Hazardous impact of $P$. hysterophorus on agriculture

\begin{tabular}{rlcccc}
\hline & Indicators & M & SD & VI & R \\
\hline 1 & contains chemicals harmful to crops & 4.21 & 0.971 & Agree & 5 \\
\hline 2 & decreases the growth of plants and trees & 4.59 & 0.663 & Strongly Agree & 1 \\
\hline 3 & affects the growth of seeds & 4.54 & 0.681 & Strongly Agree & 2 \\
\hline 4 & produces more pollen and when carried away affects the fruits of the crops & 4.50 & 0.735 & Strongly Agree & 3 \\
\hline 5 & losses and deteriorates the quality of the harvested products & 4.38 & 0.855 & Agree & \\
\hline 6 & weed infestations to vegetables and fruits crops & 4.00 & 0.904 & Agree & 6 \\
\hline 7 & inhibits the germination and growth of cereal crop, sorghum & 3.96 & 0.882 & Agree & 7 \\
\hline 8 & hinders the growth of radish & 3.68 & 0.867 & Agree & 8 \\
\hline & Composite Mean & 4.23 & 0.644 & Agree &
\end{tabular}


Table 3. Hazardous impact of $P$. hysterophorus on animals

\begin{tabular}{|c|c|c|c|c|c|}
\hline & Indicators & M & SD & VI & $\mathbf{R}$ \\
\hline 1 & toxic and causes dermatitis to horses and cattle & 3.93 & 0.868 & Agree & 2 \\
\hline 2 & if eaten, develops mouth ulcers combined with excessive salivation & 3.91 & 0.860 & Agree & 3.5 \\
\hline 3 & kills cattle if eaten much & 3.81 & 0.920 & Agree & 5 \\
\hline 4 & causes anorexia, pruritus, alopecia, diarrhea, and eye irritation among dogs & 3.47 & 0.830 & Neutral & 8 \\
\hline 5 & causes acute illness in cows and dogs when fed on grass mixed with $P$. hysterophorus & 3.91 & 0.881 & Agree & 3.5 \\
\hline 6 & weed extract reduces rat blood count & 3.52 & 0.858 & Agree & 7 \\
\hline 7 & weakens cows' immune system & 3.72 & 0.896 & Agree & 6 \\
\hline \multirow[t]{2}{*}{8} & poses serious health hazards to livestock & 4.02 & 0.834 & Agree & 1 \\
\hline & 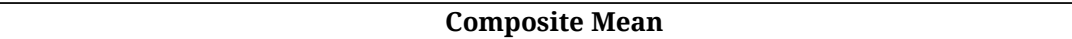 & 3.79 & 0.739 & Agree & \\
\hline
\end{tabular}

\section{Hazardous impact of $P$. hysterophorus on environment}

The indicators provided in the survey and reflected in Table 4 were all given Agree response, namely: disrupts the ecology of grasslands (WM-4.39), lowers the quality of ecosystem (WM-4.37), disturbs native vegetation (21) through aggressive competition (4.33), changes the chemical nature of the aquatic environment by altering organic matter inputs (WM-4.28), changes community structure and function through exploitation (WM-4.26), decreases species diversity and abundances (WM-

\section{Extent of responsiveness manifested to control the damage of $P$. hysterophorus}

The residents were alarmed with the presence of the weed in their respective territories and farm lands (23). They manifested measures to control the spread and damage as reflected on Table 5 with the following ratings: $4.50-5.00=$ Very Great Extent; 3.50 - 4.49 = Great Extent; 2.50 - 3.49 = Moderate Extent; $1.50-2.49=$ Least Extent; $1.00-1.49=$ Very Least Extent. The following are the indicators that were assessed with Great Extent:: manual uprooting and burning of the weed before flowering (24) and seed

Table 4. Hazardous impact of $P$. hysterophorus on environment

\begin{tabular}{|c|c|c|c|c|c|}
\hline & Indicators & $\mathbf{M}$ & SD & VI & $\mathbf{R}$ \\
\hline 1 & lowers the quality of ecosystem & 4.37 & 0.791 & Agree & 2 \\
\hline 2 & changes community structure and function through exploitation & 4.26 & 0.840 & Agree & 5 \\
\hline 3 & decreases species diversity and abundance & 4.20 & 0.831 & Agree & 6 \\
\hline 4 & contaminates water flow and sedimentation & 3.71 & 0.903 & Agree & 9 \\
\hline 5 & reduces soil nutrient levels & 4.07 & 0.843 & Agree & 7 \\
\hline 6 & changes community structure and function through exploitation & 3.99 & 0.834 & Agree & 8 \\
\hline 7 & changes the chemical nature of aquatic environment by altering organic matter inputs & 4.28 & 0.795 & Agree & 4 \\
\hline 8 & disrupts the ecology of grasslands & 4.39 & 0.794 & Agree & 1 \\
\hline \multirow[t]{2}{*}{9} & disturbs native vegetation through aggressive competition & 4.33 & 0.797 & Agree & 3 \\
\hline & Composite Mean & 4.18 & 0.678 & Agree & \\
\hline
\end{tabular}

4.20), reduces soil nutrient levels (22) with (WM4.07), changes community structure and function through exploitation (WM-399) and contaminates water flow and sedimentation (WM-3.71). A fivepoint scale justified the responses: $4.50-5.00=$ Strongly Agree; $3.50-4.49=$ Agree $; 2.50-3.49=$ Neutral; $1.50-2.49=$ Disagree; $1.00-1.49=$ Strongly Disagree. setting (WM-4.38), hand weeding (WM-3.85), planting native plants to replace the weed (WM-3.81) and using plant species with biological control agent (WM-3.35).

Other indicators that garnered Moderate Extent responses include: ploughing the weed in the rosette stage (WM-3.33), using insects and botanicals (WM3.20), burning (WM-3.20), using appropriate and

Table 5. Extent of responsiveness manifested to control the damage of $P$. hysterophorus

\begin{tabular}{llcccc}
\hline & Indicators & M & SD & VI & R \\
\hline 1 & $\begin{array}{l}\text { manual uprooting and burning of the weed before flowering and seed } \\
\text { setting }\end{array}$ & 4.38 & 0.867 & Great Extent & 1 \\
\hline 2 & spraying sodium chloride & 3.07 & 1.223 & Moderate Extent & 9 \\
\hline 3 & ploughing the weed in the rosette stage & 3.33 & 1.293 & Moderate Extent & 5 \\
\hline 4 & hand weeding & 3.85 & 1.200 & Great Extent & 2 \\
\hline 5 & burning & 3.20 & 1.401 & Moderate Extent & 7 \\
\hline 6 & use of chemical herbicides & 2.85 & 1.318 & Moderate Extent & 12.5 \\
\hline 7 & spraying glyphosate and metribuzin & 2.79 & 1.226 & Moderate Extent & 14 \\
\hline 8 & planting plants to replace parthenium & 3.81 & 1.225 & Great Extent & 3 \\
\hline 9 & using insects and botanicals & 3.20 & 1.280 & Moderate Extent & 6 \\
\hline 10 & using appropriate and exotic bioagent such as bacteria, fungi & 3.11 & 1.281 & Moderate Extent & 8 \\
\hline 11 & fungal pathogens & 2.91 & 1.218 & Moderate Extent & 10 \\
\hline 12 & powdery mildew leading to defoliation & 2.91 & 1.235 & Moderate Extent & 11 \\
\hline 13 & plant species with biological control agent & 3.35 & 1.247 & Moderate Extent & 4 \\
\hline 14 & leaf-feeding beetle $\quad$ Composite Mean & 2.85 & 1.377 & Moderate Extent & 12.5 \\
\hline & & 3.26 & 0.848 & Moderate Extent
\end{tabular}


exotic bio agent such as bacteria, fungi (WM-3.11), spraying sodium chloride (WM-3.07), spraying fungal pathogens (WM-2.91), applying powdery mildew leading to defoliation (WM-2.91), giving chemical herbicides (WM-2.85), using leaf-feeding beetle (25) (WM-2.85), and spraying glyphosate and metribuzin (WM-2.79).

\section{Problems encountered by the affected residents in removing $P$. hysterophorus}

Table 6 exhibits the responses extended to the problems that were encountered in removing the weeds based on a five-point likert scale: $4.50-5.00=$ Always; $3.50-4.49=$ Frequently; $2.50-3.49=$ Sometimes; $1.50-2.49$ = Seldom; $1.00-1.49=$ Never . Majority of the problems frequently encountered were: weeds grow faster (26) than native plants and compete for available nutrients (WM-4.27), weeds replace the native plants that animals use for grazing (27) (WM-4.20), rainfall is seasonal, and underground wells and springs are the only natural sources of drinking water (WM-4.07), lack of mowing equipment (WM-3.94), the soil is loamy in most parts of wastelands (WM-3.92), solar radiation and high temperature affect the health of the people who volunteered to remove the weeds (WM-3.89), weeding is costly (WM-3.88), lack of knowledge to monitor the spread and growth of the weed (WM3.86), insufficient knowledge of the noxious weed (WM-3.66) and unavailability of gloves and protective clothing to prevent absorption of toxins through the skin (WM-3.56). Whereas, the indicators with Sometimes responses from the participants include: digging the soil kills microorganism that degrades its quality (WM-3.27), soils are affected by the pulling of weeds (WM-3.00) and local plants within the proximity are affected by the pulling of weeds (WM2.90). Added to those scenarios, it was found out that farmers were still unequipped with the proper knowledge on the biological control option to manage $P$. hysterophorus (28).

\section{Significant differences of responses when grouped according to profile}

The hazardous impact of $P$. hysterophorus, the extent of responsiveness manifested in controlling its damage and the problems encountered in controlling its spread (29) were grouped accordingly to determine the significant differences (16) as shown on Table 7.

With the significant $\mathrm{p}$-value $<0.05$, it was found out that significant differences were observed justified by the obtained P-value of 0.013 . Since the obtained p-values were less than 0.05 alpha level, all their responses differed significantly, emphasizing that with regards to assessment and awareness of the matters about the weed, the academicians appeared to have broader and greater assessment including awareness. Knowledge wise, academicians are aware of the biology of the weed and how it spreads (30). It went similar with the extent of responsiveness manifested in controlling the damage done by the plant.

However, there was no significant difference found when grouped according to the respondents' gender. This explains that all the respondents were

Table 6. Problems encountered in removing P. hysterophorus

\begin{tabular}{|c|c|c|c|c|c|}
\hline & Indicators & $\mathbf{M}$ & SD & VI & $\mathbf{R}$ \\
\hline 1 & $\begin{array}{l}\text { rainfall is seasonal in Dhofar governorate, and underground wells and springs are the only } \\
\text { natural sources of drinking water }\end{array}$ & 4.07 & 1.007 & Frequently & 3 \\
\hline 2 & local plants are affected by pulling of weeds & 2.90 & 1.299 & Sometimes & 13 \\
\hline 3 & soils are affected by the pulling of weeds & 3.00 & 1.313 & Sometimes & 12 \\
\hline 4 & insufficient knowledge of the weeds & 3.66 & 1.038 & Frequently & 9 \\
\hline 5 & digging the soil kills microorganisms that degrades the quality of it & 3.27 & 1.061 & Sometimes & 11 \\
\hline 6 & weeding is costly & 3.88 & 1.034 & Frequently & 7 \\
\hline 7 & weeds grow faster than native lands and compete for available nutrients & 4.27 & 0.962 & Frequently & 1 \\
\hline 8 & weeds replace the native plants that animals use for grazing & 4.20 & 0.957 & Frequently & 2 \\
\hline 9 & solar radiation and high temperature cause problems for people while removing the weed & 3.89 & 1.022 & Frequently & 6 \\
\hline 10 & The soil is loamy in most parts of Dhofar mountains & 3.92 & 0.896 & Frequently & 5 \\
\hline 11 & lack of knowledge to monitors the spread and growth of the weeds & 3.86 & 0.971 & Frequently & 8 \\
\hline 12 & lack of mowing equipment & 3.94 & 1.073 & Frequently & 4 \\
\hline \multirow[t]{2}{*}{13} & $\begin{array}{l}\text { unavailability of gloves and protective clothing to be worn to prevent absorption of toxins } \\
\text { through the skin }\end{array}$ & 3.56 & 1.096 & Frequently & 10 \\
\hline & Composite Mean & 3.72 & 0.630 & Frequently & \\
\hline
\end{tabular}

Table 7. Significant differences of responses when grouped according to profile

\begin{tabular}{|c|c|c|c|c|c|c|c|c|}
\hline & \multicolumn{4}{|c|}{ Gender } & \multicolumn{4}{|c|}{ Group } \\
\hline & $\begin{array}{c}\text { t- } \\
\text { value }\end{array}$ & $\begin{array}{c}\text { p- } \\
\text { value }\end{array}$ & $\mathbf{D}$ & $\mathbf{I}$ & $\begin{array}{c}\text { F- } \\
\text { value }\end{array}$ & $\begin{array}{c}\text { p- } \\
\text { value }\end{array}$ & D & I \\
\hline Impact to health & 1.098 & 0.273 & Fail to Reject & NS & 1.499 & 0.120 & Fail to Reject & NS \\
\hline Impact to agriculture & 0.927 & 0.355 & Fail to Reject & NS & 1.142 & 0.326 & Fail to Reject & NS \\
\hline Impact to animals & 1.257 & 0.210 & Fail to Reject & NS & 1.463 & 0.134 & Fail to Reject & NS \\
\hline Impact to environment & 0.763 & 0.446 & Fail to Reject & NS & 1.061 & 0.395 & Fail to Reject & NS \\
\hline $\begin{array}{l}\text { Extent of responsiveness manifested in } \\
\text { controlling the damage done by } P \text {. } \\
\text { hysterophorus }\end{array}$ & 0.309 & 0.758 & Fail to Reject & NS & 2.146 & 0.013 & Rejected & $S$ \\
\hline $\begin{array}{l}\text { Problems encountered by the affected } \\
\text { residents in removing } P \text {. hysterophorus }\end{array}$ & 1.540 & 0.125 & Fail to Reject & NS & 2.582 & 0.003 & Rejected & $S$ \\
\hline
\end{tabular}

Legend: Significant at p-value $<0.05$ 
aware towards the impact that would directly be hazardous once contacted with the plant (31).

\section{Discussion}

\section{Impact of parthenium weed on human health}

Diseases caused by $P$. hysterophorus cause various allergies sush as dermatitis, rhinitis, asthma and atopic dermatitis. The detrimental health effects of the weed are attributed to the sesquiterpene lactones and in particular parthenin in the plant which are toxic to farm animals and responsible for allergic diseases in humans (32). As the weed continues to spread throughout Dhofar governorate, follow-up information and feedback from the affected residents need to be collected and monitored for proper management and control measures. Constant coughing during nightime, nausea, dizziness, watery
Another resident, Ahmed Shamas, experienced the same skin allergy brought by the poison of the weed. He suffered with fever and skin irritation that lasted for five days (Fig. 4).

\section{Impact of $P$. hysterophorus on agriculture}

The weed is the most destructive invasive plant species, threatening biodiversity, food security and human health across the governorates of Oman. $P$. hysterophorus became a major plant problem following natural disasters when it invaded and continued to spread across southern part of Dhofar, The weed is considered destructive as it kills the plants within close proximity through allelopathy alarmingly could wipe out the entire farm lands (34). At this point in time, the incredible destructions are being noticed and found difficult to control its invasion in most areas. The presence and abundance of the weed poisons livestock resulting to decreased

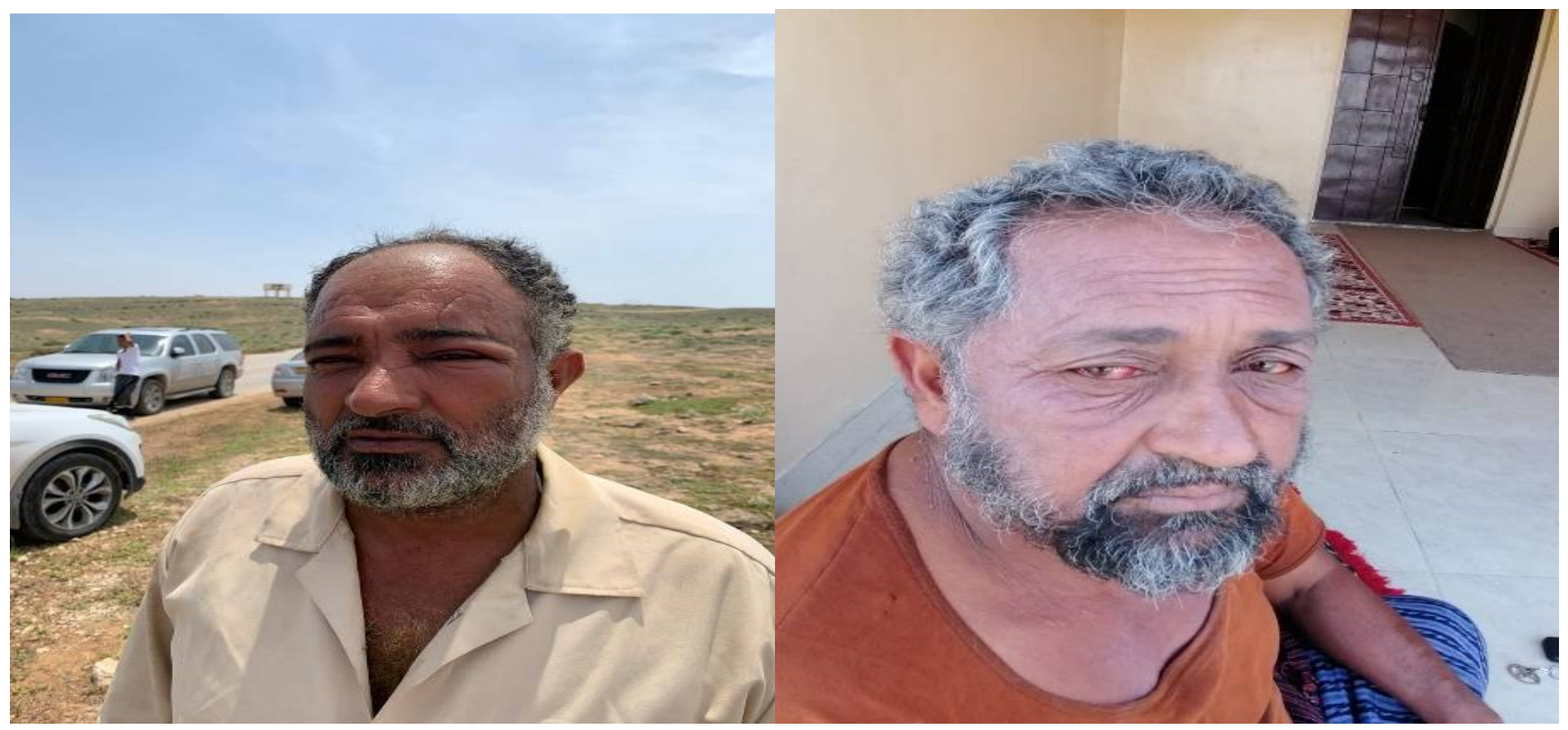

Fig. 3. The hazardous impact of the weed to human health as experienced by some residents of Dhofar.

eyes, runny nose, frequent sneezing, fatigue and asthmas are common health hazards that the municipality and responsible agencies must prioritize to give attention to.

There was hazardous impact directly experienced by the volunteers when they handpulled the weeds as shown in Fig. 3 dated August 22, 2020. Issa Shamas, a resident of Shamas tribe in Salalah, volunteered in removing the abundant weeds not knowing of the consequence of catching allergy. With the constant wiping of sweats using his bare hands, he was infected by the weed poison (33). Human health impact started to increase since most residents could not completely avoid contact with the plant. They are aware that they could be free of the health danger once they vacate their places, until thinking that this is impossible for them. The investigator of this study initiated to conduct removal of weeds along Airdit, Wilayat Rakhyout, Dhofar on 22 August 2020. His intention is to personally determine the what-would-be-effects to humans, until he positively found the strong motive to continue with his investigation. grazing capacity of the land.

\section{Impact to biodiversity}

The main threatening factors to biodiversity in Oman are habitat destruction which includes desertification, changes of soil characteristics, too much harvesting, overgrazing, urbanization, chemical pollution considering nitrate, pesticide sand heavy metal. Added to these are the invasive species most likely the this kind of weed. The increase in the growing of $P$. hysterophorus in Dhofar is mainly attributed to habitat loss because of overgrazing and development. Also considered are the possible climate change, off-road driving, ecosystem modification and littering. These threats lead to the loss or decline of plant populations (35).

The results and findings of the study revealed that $P$. hysterophorus is hazardous to human health, to agriculture and to environment. It is devastating to the ecosystem thus, a formal eradication should takes place as soon as possible to protect the biodiversity. It poisons livestock which then channeled to human 


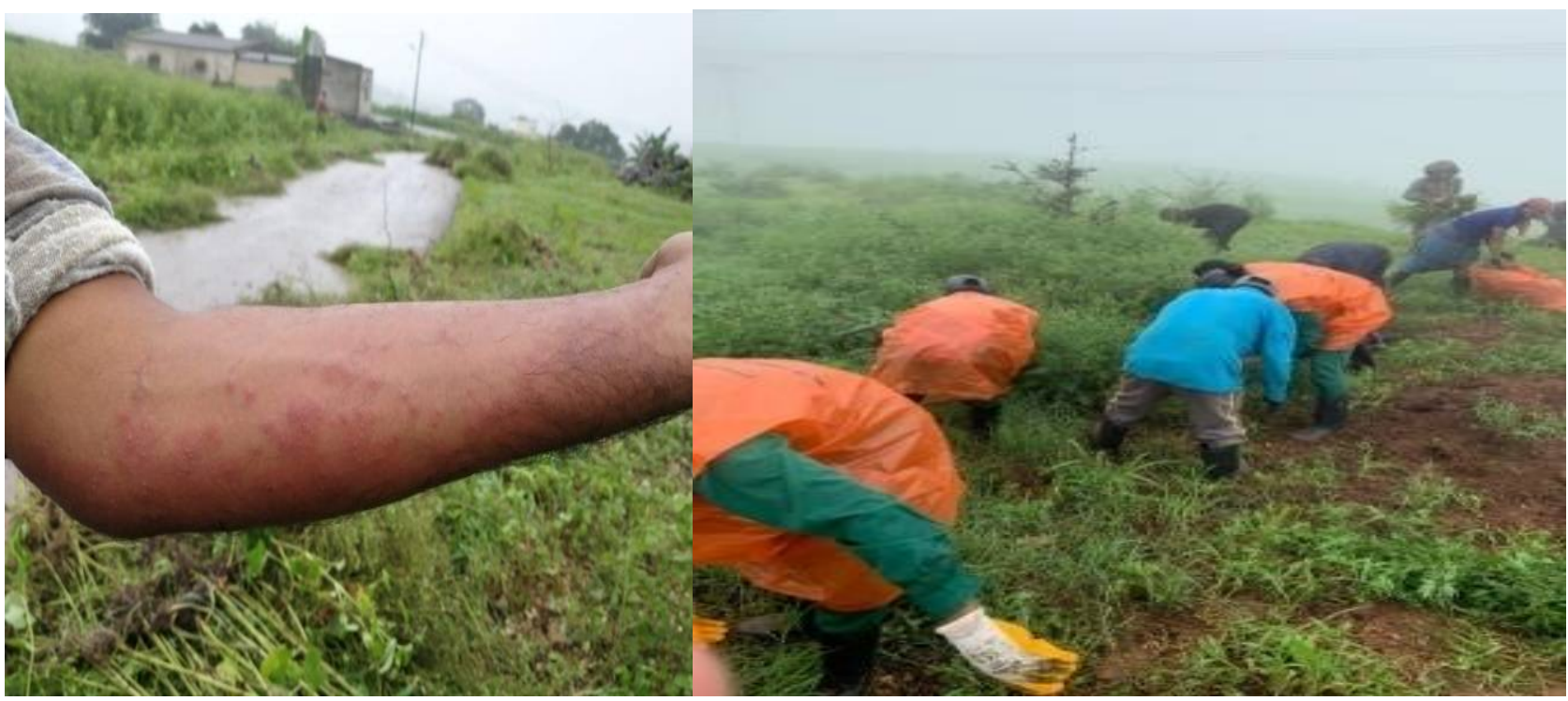

Fig. 4. Skin allergy as experienced by a resident of Dhofar after participating in hand-pulling of the weed.

health resulting to death once consumed in large quantities (36). The divergent cultural, physical, chemical and biological management control solutions from the respondents show that they are eager, sensible enough and imbibed with spirit of commitment not just to eliminate but to totally destroy them. Until now, the implementation of any control measures has not been in placed systematically among the affected areas in southwestern part of the Sultanate of Oman. It was also concluded that the residents of Dhofar are aware on the spread of this plant. They are ready to support whatever actions the government will implement. Here, threats to plant species diversity and vegetation cover can also be inferred from land use degradation (desertification) and pollution as exhibited by the

\section{Focus group discussions (FGD)}

The last part of the survey was conducted by means of focus group discussion. It summarized the possible control measures given directly to the facilitator and the investigator himself, and these include: burning the alive plants during summer time or prior to rainy season; mechanical removal of the weeds before it reached flowering stage (38); financial support to the affected land owners; raising public awareness; studying its components for there might be extracts of useful elements e.g for pesticide; immediate replacement of common crops once the uprooting of the weed has done; utilizing bulldozers and related modern heavy equipment in uprooting the weeds; establishing an integrated research centre

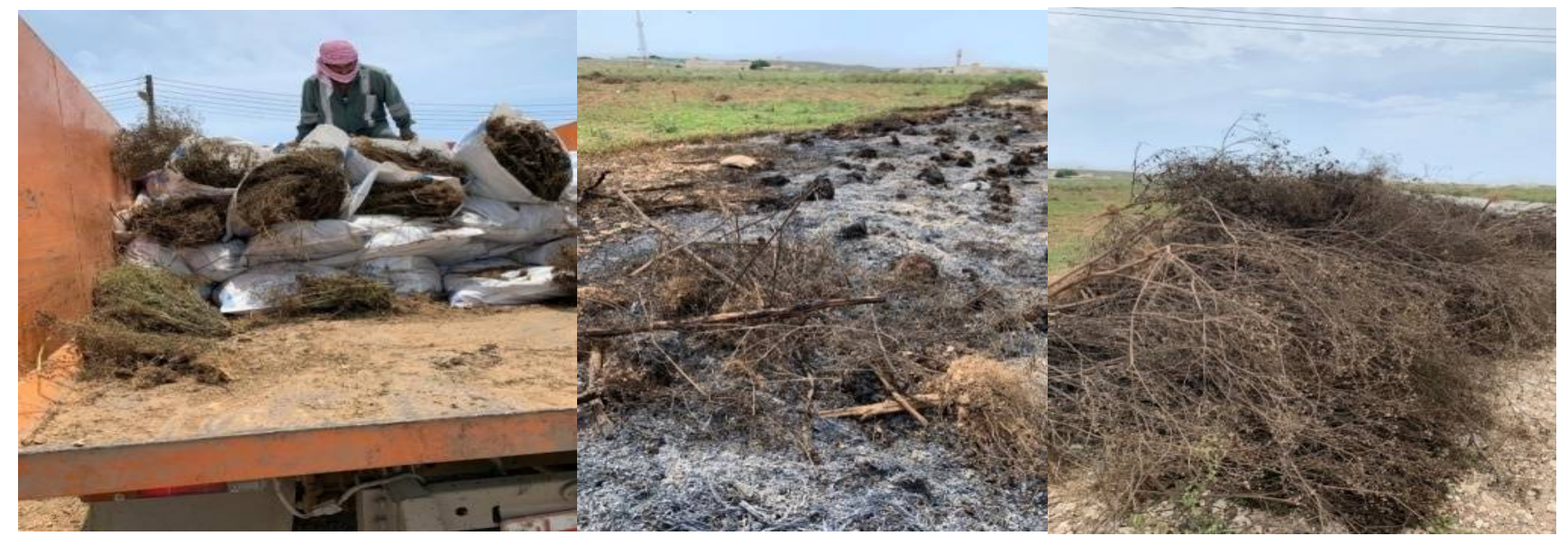

Fig. 5. The hazardous impact of $P$. hysterophorus to biodiversity.

concerned residents and volunteers in Fig. 5. Terrestrial lands of Oman depend mainly on perennial plants with availability of annual plant species, for fodder, only after rain. it can degrade what was once suitable land for farming purposes, resulting in major economic losses to some smalltime farmers. If left unmanaged, this weed could cause crop yield losses of up to $95 \%$, with what little is successfully harvested potentially being of much less commercial value due to contamination (37). intended for this invasive plant; allocating certain funds to hire experts who will develop modern and safe methods for combating weeds; filling, paving and grinding of the roadsides for at least 3 metres to protect the land from the falling seeds; hand hoeing during the early growth stages and similar action for car parks especially during autumn as the cows and cattle sit on this area; a need to breed effective natural enemies to weaken till stop enhances its ability to spread very quickly (39). 
It was August 30, 2020 when the author recorded for the first time, the presence of the weed in one farm in Wilayat Al Qabil, North Sharqiyah governorate. Coordinates and location of the point suggests: Point Y, Point_X, respectively: 22.739090, 58.691151. In September 2020, another recording of the presence of $P$. hysterophorus was done in Wilayat Al Kamil and Al Wafi in South Sharqiyah governorate emphasizing coordinates and location such that: Point_Y, Point_X, respectively: 22.22028275, 59.20948478. Similarly, in Tanuf area along Nizwa, Ad Dakhiliyah governorate; coordinates and location of a point is: Point_Y, Point_X, respectively: 23.052985, 57.459599, and in Wadi Bani Hani in wilayat Rustaq, Batinah in south governorate; coordinates and location of a point is: Point_Y, Point_X, respectively:23.454565, 57.316006. With those pointed locations, it is highly recommended to conduct deeper scientific investigation to determine the presence of the rapid spread of $P$. hysterophorus found to have started invading the different governorates of Oman.

\section{Weed management challenges}

Despite the actions done to eliminate and control the growing back of $P$. hysterophorus, there are certain weed challenges that delay and sometimes hinder their goals to eradicate them. Farmers experienced challenges in the use of herbicides' suitability. Along with the plantation owners they had proven the effectiveness of using herbicides for couple of years. However, they can damage native plants, insects and even harm human health if much exposed. Choosing the suitable herbicide became a challenge to the farmers of Dhofar (40).

Reduction in crop yield and competing with the native crops for water, nutrients through fertilizers and sunlight are another challenges that bother the farmers resulting to severe destruction in the farmlands.. Plantation managers hate to admit that $P$. hysterophorus grow faster than their good crops and consume more amount of water and nutrients, thus causing heavy losses in yield. Meanwhile, the quality of field produce has been reduced too. They noticed that when they harvested good crops and happened to have presence of weeds, unknowingly their seeds of have tendency to mix with the main crops and this results to lowering their quality (41).

Lack of mowing equipment is another challenge as declared by the key informants. This is the reason why they rely on some DIY strategies and most often than not, found to be successful. Similarly, inadequate soil preparation and compost is frequently observed by famers. Soil preparation is crucial to a flourishing plantation. This is neglected oftentimes because soil preparation is a tedious farming for them, thus, resulting to unpreparedness of the soil to accommodate good plants. Compost should then be applied to prepare the soil ready for planting. Solar radiation and high temperature cause problems for people while removing the weeds are significant for them, to, which falls from the month of April till July (2).

In this time, weeding is costly and there is frequent increase in the cost of cultivation. Those residents who can afford tilling operations invest large amount to control weeds. With the high expenditures in weeding, most of the time, they apply other methods to control the spread of parthenium, or else, their margin of net profit will definitely be reduced (42). The lack of knowledge to monitor the spread and growth of the weeds is another challenge. Majority of the affected farmers are unaware of weed management, weed-crop-soil interactions and their practical significance in field conditions. This is important for them to be indulged in a more precise soil management and crop rotation strategies to give crops an edge over particular weed species.

Fig. 6 is an example of weed-plant relationship that the concerned and affected residents must be aware of.

Weeds harbor insect, pests and diseases (43) are major challenges the residents are facing with. In some situations, $P$. hysterophorus could have both positive and negative effects on crop productivity (44). They confuse insects to locate their best foods and shelters. Most often insects and other pests were confused where they go because there are plants that looked alike parthenium. Thus, crops that are closely similar to this weed, weeds became exempted in harboring insects that attack those crops. Unavailability of gloves and protective clothing to be worn to prevent absorption of toxins through the skin has sometimes challenged the farmers. There were times that they were surprised by the sudden invasion and when they wanted to pull them out, there were no available gloves and protective clothing to protect them from the harm that the weeds may bring to them.

Moreover, weeds reduce the value of land. Agricultural lands which are heavily infested are likely to fetch less prices (45). Both seller and buyer are aware that such land will be difficult to cultivate unless they invest for soil compost, labour and machinery, resulting to increase in the cost of cultivation. Interplanting or popularly known as

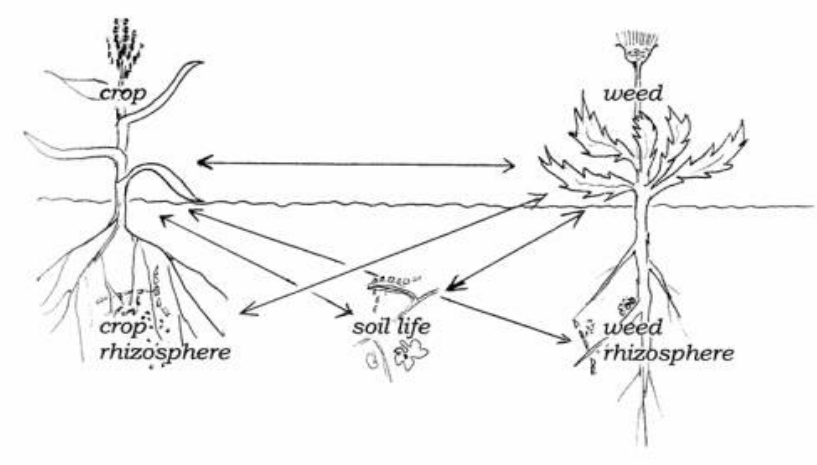

Fig. 6. The linkage between and among crops, weeds and soil life found significant in weed-suppressive crop rotations is a potential knowledge the farmers should know (Figure credit: Mark Schonbeck, Virginia Association for Biological Farming).

close planting has been considered a challenge to cropland owners (46). They see to it that even they plant different crops on the same plot or bed, they are close enough not to penetrated by the invasion of weeds. They reduce the allotted standard distances 
for the crops to discourage the coming of unwanted plants (47). Before planting, they made sure that the soil is fertile enough to feed high densities of crop.

\section{Conclusion}

$P$. hysterophorus has the ability to spread and invade the most wastelands and green areas of Dhofar governorate, Oman. The investigation proves that the presence of the weed has to be given possible control measures to protect the natural biodiversity (48). The support and involvement of the government through the Environment Authority, Ministry of Agriculture, Fisheries and Water Resources, the Ministry of Health including the joint working teams created to deal with the weed in Dhofar governorate are very timely to take the lead. Knowing the results and confirmation of the dangers of the plant, prioritizing attention and focus to detect and monitor germination and invasion of new plants are essential (49). Farmers as well as households' knowledge on how the plant spreads and how they could be managed and controlled has not yet given attention by the responsible agencies. The invasion of this alien species started to create dangers (50) that are being faced now in Dhofar particularly the farmland owners, agriculture managers, planters, crop caretakers and even the residents. The non-formal documentation and records of parthenium in this country prompted the researcher-investigator to commit and undergo initial observation regarding its spread, the whereabouts, the distribution, abundance and infestation created in the crop fields (51). This is the foremost reason why this plant issue has never been resolved yet by any agencies in accordance with $\mathrm{EA}, \mathrm{MOH}$ and the MAFWR.

\section{Recommendation}

Further research to forego deeper study on the major causes of the spread must be conducted. Formal eradication should take place as soon as possible since the damage caused by the parthenium weed is alarming. Management plans to develop intervention that will ensure smart and practical strategies to contain parthenium and to slow its further spread (52) must be considered by the joint working teams assigned in Dhofar. It is also important to communicate to the different governorates how the weed can be identified and how the people can eradicate them by either chemical or mechanical meansfor the conservation status of habitats in the affected areas (53). It is of utmost importance to monitor further the spread and population density (54) among the remaining ten governorates in the entire sultanate to emphasise the possible control measures after knowing the following locations of partnenium abundance.

\section{Acknowledgements}

The author expresses his appreciation of thanks to the Proprietor and CEO of AAE Environmental Engineering Consultants for funding this research study and to his family for the unending support during site visits monitoring and determining the presence and abundance of the weed. More so, to Dr. Shahina A Ghazanfar, Honorary Research Associate, Royal Botanic Gardens Kew, UK for editing the manuscript and to Mr. Mohammed Mubarak Suhail Akaak, educational researcher, Ministry of Education-Oman for sharing some of the GPS coordinates of $P$. hysterophorus sites at Dhofar Mountains, Oman.

\section{Conflict of interests}

The author declares no conflict of interest regarding the publication of this article.

\section{References}

1. Surinder SR. Crop-weed competition. Department of Agronomy, CSK Himachal Pradesh Krishi Vishvavidyalaya, Palampur 176062, HP, India; 2020.

2. Ghazanfar SA. Parthenium hysterophorus L., as invasive weed in Southern Oman. Parthenium news 13, January and July 2017; https://apwss.otg/documents/newsletter/parthenium

3. Håkanson S. Weeds and weed management on Arable land: An ecological approach. CABI Publishing, Wallingford, UK [Google Scholar]; 2003. https://doi.org/10.1079/9780851996516.0000

4. Bisikwa J. Parthenium weed distribution and management in Uganda. In: programme and abstracts; 2010.

5. Zimdahl R. Weed-crop competition: A Review. Blackwell Publishing, Oxford; 2004. https://doi.org/10.1002/9780470290224

6. Kumar S. A new disease of Parthenium hysterophorus incited by an undescribed species of Cryptosporiopsis. October 2000 , Vol. 84, Number 10, APS Publications. 2007. https://doi.org/10.1094/PDIS.2000.84.10.1151A

7. Dhileepan K. Managing Parthenium weed across diverses landscapes: Prospects and limitations. Springer, Netherlands; 2009.

8. Lawrence O. Principles of weed threshold research. Weed Technology. https://doi.org/10.1017/S0890037X00032152

9. Liamputtong P. Focus group discussions methodology: Principles and practice; 2011. https://doi.org/10.4135/9781473957657

10. Sushil K. Current spread, impact and management of Parthenium hysterophorus L. in India. Intl Parthenium News. 2012;5:1-6.

11. George A. Statistics for Research with Guide to SPSS. University of New South Wales Australia, SAGE Publications Ltd; 2011.

12. Adkins. Parthenium weed poses danger to crops. Published in Dhaka Mirror, December 30, 2009.

13. Rana SS. Weed management. Department of Agronomy, College of Agriculture, CSK HP Krishi Vishvavidyalaya, Palampur; 2020.

14. Roy S, Edward B. Statistical research methods: A guide for nonstatistician. Springer Verlag, New York; 2013.

15. Patzelt A. Oman plant: Red Data Book. Oman Botanic Garden; 2015.

16. Miller AG, Morris M. Plants of Dhofar, the southern region of Oman, traditional, economic and medicinal uses. The Office of the Advisor for Conservation of the Environment, Diwan of Royal Court, Oman; 1988.

17. Karim R. Weed problems and their management in rice fields of Malaysia: An overview. Weed Biology and Management 2017;4(4):177-186.

18. Ali S, Khan IA. Management of Parthenium hysterophorus using suppressive plants. Malaysian Journal of Science. 2017; 
(2):75-84.

19. Nguyen $\mathrm{T}$ et al. Impact of an invasive weed, Parthenium hysterophorus, on a pasture community in South East Queensland, Australia. Environmental Science and Pollutionc Research. https://doi.org/10.1007/s11356-017-0327-1

20. Shabbir A, Adkins SW. Parthenium weed: Management Prospects in Pakistan. In: RD van Klinken, VA Osten, FD Panetta and JC Scanlan, (eds.).In: Proceedings of the 16th Australian Weeds Conference. Queensland Weeds Society, Brisbane; 2008; p. 271.

21. Schonbeck M, McCann B. Cultural practices for managing weeds [Interactive Online Course]. Module D. In: Integrated Pest Management for Organic Crops. Cooperative Extension Curriculum Project; 2007.

22. Sarah EP, Benjamin LR, Watkinson AR. The theory and application of plant competition models: an agronomic perspective. Annals Botany. Dec;2003;92(6):741, Oxford University Press. https://doi.org/10.1093/aob/mcg204

23. Shabbir A, Bajwa AA, Dhileepan K, Zalucki M, Khan N, Adkins S. Integrated use of biological approaches provides effective control of parthenium weed. Archives of Agronomy and Soil Science. https://doi.org/10.1080/03650340.2018.1464150

24. Masum SM, Mirza H, Ali MH. Threats of Parthenium hysterophorus on Agroecosystems and its Management: A Review. www.ijagcs.com IJACS/2013/6-11/684-697 ISSN 2227670X (C2013 IJACS Journal Faculty of Agriculture, Shere-Bangla Agricultural University, Dhaka 1207, Bangladesh; 2013.

25. Mohler CL, DiTommaso A. Unpublished. Manage weeds on your farm: a guide to ecological strategies; version 5.1, Cornell University; 2008.

26. Nguyen T, Bajwa AA, Navie S, O’Donnell C, Adkins S. Parthenium weed (Parthenium hysterophorus L.) and climate change: the effect of $\mathrm{CO}_{2}$ concentration, temperature and water deficit on growth and reproduction of two biotypes. Environmental Science and Pollution Research. 2017;24(11). https://doi.org/10.1007/s11356-017-8737-7

27. Ghazanfar SA. Status of the flora and plant conservation in the Sultanate of Oman. Biological Conservation. 1998;85:275-85. https://doi.org/10.1016/S0006-3207(97)00162-6

28. Asad S et al. Spread of Parthenium weed and its biological control agent in Punjab, Pakistan. In: Conference Proceedings of the 23rd Asia-Pacific Weeds Science Society Conference: Weed Management in a Changing World, Cains, Queensland, Australia, 2011;497-503.

29. Adkins SW, Shabbir A. Biology, ecology and management of the invasive Parthenium weed (Parthenium hysterophorus L.). Pest Management Science. 2014;70:1023-29. https://doi.org/10.1002/ps.3708

30. Håkanson S. Weeds and weed management on Arable Land: an ecological approach. CABI Publishing, Wallingford, UK; 2003.

31. Aneja KR, Dhawan SR, Sharma AB. Deadly weed, Parthenium hysterophorus L. and its distribution. Indian Journal of Weed Science. 1991;23:14-18.

32. Ivan R, Julien LG, Kate C, Fernadis M, Winnie N, Roger D, Philip W, Pablo GM. 2019. Parthenium: Impacts and coping strategies in Central West Asia. Technical report; 2019. https://www.researchgate.net/publication/342068567

33. $\mathrm{CAB}$ International. Parthenium fact sheet. Crop Protection Compendium, 2007 edn. CAB International, Wallingford, UK; 2007.

34. Ayana E, Ensermu K, Teshome S. Impact of Parthenium hysterophorus L. (Asteraceae) on herbaceous plant biodiversity of Awash National Park (Anp), Ethiopia. 2011;2:69-80. https://doi.org/10.3391/mbi.2011.2.1.07

35. Adkins SW, Navie SC. Parthenium weed: a potential major weed for agro-ecosystems in Pakistan. Pakistan Journal of Weed Science Research. 2006;12:19-36.

36. Chamberlain J, Gittens A. Parthenium weed management: Challenges, opportunities and strategies. Parthenium Action
Group. The State of Queensland (Department of Natural Resources, Mines and Energy), Brisbane, Australia; 2004; 82 pp.

37. Asresie. Impact of Parthenium (Parthenium hysterophorus L.) on Herbaceous vegetation and soil seed bank flora in grazing lands and sorghum fields in Eastern Amhara, Ethiopia. M.Sc. Thesis, Haramaya University, Ethiopia; 2008.

38. Rana SS, Rana MC. Advances in weed management. Department of Agronomy, College of Agriculture, CSK Himachal Pradesh Krishi Vishvavidyalaya, Palampur;2015;183 pp. https://doi.org/10.13140/RG.2.2.26235.72487.

39. Sullivan P. Principles of sustainable weed management for croplands [Online]. ATTRA Publication \#PO39. National Sustainable Agriculture Information Service; 2003.

40. Ministry of Environment and Climate Affairs $5^{\text {th }}$ National Report to the Convention on Biological Diversity (CBD); 2014.

41. Karki D. Ecological and socio-economic impact of Parthenium hysterophorus L. Invasion in Two Urban Cities of South-Central Nepal. MSc thesis, Central Department of Botany, Tribhuvan University, Kathmandu, Nepal; 2009.

42. Melander B. Rasmussen IA, Barberi P. Integrating physical and cultural methods of weed control: examples from European research. Weed Science. 2005;53(3):369-81. https://doi.org/10.1614/WS-04-136R

43. Kumar S, Angiras NN, Rana SS, Praveen S. Crop weed competition studies in Okra [Abelmoschus esculentus (L.) Moench] under mid hill conditions of Himachal Pradesh. Himachal Journal of Agricultural Research. 2010;36(1):13-19.

44. Ray P, Gour HN. Integrated management of Parthenium hysterophorus L. (Asteraceae): A weed of worldwide significance. Indian Society of Mycology and Plant Pathology.2012;5:605-32. View at: Google Scholar.

45. Wahab S. Management of Parthenium through an integrated approach initiatives, achievements and research opportunities in India. University of Agricultural Sciences, Bangalore, India; 2005.

46. Rao VS. Principles of weed science, Second Edition. Routledge Publishing; 2000. https://doi.org/10.1201/9781482279603

47. Christoffoleti PJ. Herbicide selectivity by differential metabolism: considerations for reducing crop damages. Scientia Agricola. 2009;66(1):136-42. https://doi.org/10.1590/S0103-90162009000100020

48. Adkins SW, Navie SC, Dhileepan K. Parthenium weed in Australia: Research progress and prospects. In: Ramachandra Prasad TV, Nanjappa HV, Devendra R., Manjunath A. Subramanya SC et al. (eds) Proceedings of the Second International Conference on Parthenium Management. University of Agricultural Sciences, Bangalore, India; 2005;1127.

49. Gaikwad CB, Kasture MC, Lambade BM. Evaluation of herbicides for control of Parthenium in waste land. Indian Journal of Weed Science. 2008;40(1):79-81

50. Bajwa AA et al. Weed seed spread and its prevention: the role of roadside wash down. Journal of Environmental Management.
2018;208:8-14 https://doi.org/10.1016/j.jenvman.2017.12.010

51. Asad S. Towards the improved management of Parthenium weed: Complementing biological control with plant suppression [Ph.D. thesis], School of Agriculture and Food Sciences, University of Queensland; 2012.

52. Bowen D, Ji J, Adkins SW. Management of Parthenium weed through competitive displacement with beneficial plants: a field study. A report to the Queensland Murray Darling Committee. Brisbane, Australia: The University of Queensland; 2007.

53. Reginald V. Biodiversity conservation in Oman: Current status and future options. USQ. Oman, 2014. http://www.nizwa.net/env/biodiversity/biodiversity.html

54. Bajwa AA, Chauhan BS, Adkins SW. Germination ecology of two Australian biotypes of ragweed Parthenium (Parthenium hysterophorus) Relates to their Invasiveness. Weed Science. 2018;66(1):62-70. https://doi.org/10.1017/wsc.2017.61 